\title{
Getting to the heart of intracellular glucocorticoid regeneration: 11ק-HSD1 in the myocardium
}

\author{
Gillian A Gray, Christopher I White, Raphael F P Castellan, Sara J McSweeney and \\ Karen E Chapman
}

University/BHF Centre for Cardiovascular Science, Queen's Medical Research Institute, University of Edinburgh, Edinburgh, UK

Abstract

Corticosteroids influence the development and function of the heart and its response to injury and pressure overload via actions on glucocorticoid (GR) and mineralocorticoid (MR) receptors. Systemic corticosteroid concentration depends largely on the activity of the hypothalamic-pituitary-adrenal (HPA) axis, but glucocorticoid can also be regenerated from intrinsically inert metabolites by the enzyme $11 \beta$-hydroxysteroid dehydrogenase type 1 (11 $\beta$ HSD1), selectively increasing glucocorticoid levels within cells and tissues. Extensive studies have revealed the roles for glucocorticoid regeneration by $11 \beta-H S D 1$ in liver, adipose, brain and other tissues, but until recently, there has been little focus on the heart. This article reviews the evidence for glucocorticoid metabolism by 11 $\beta$-HSD1 in the heart and for a role of $11 \beta$-HSD1 activity in determining the myocardial growth and physiological function. We also consider the potential of $11 \beta-H S D 1$ as a therapeutic target to enhance repair after myocardial infarction and to prevent the development of cardiac remodelling and heart failure.
\end{abstract}

Correspondence should be addressed to G A Gray Email gillian.gray@ed.ac.uk

\section{Introduction}

The major physiological adrenocorticosteroid hormones, glucocorticoids (cortisol in most animals and corticosterone in rats and mice) and mineralocorticoids (aldosterone) are vital for normal cardiovascular function. They regulate blood pressure (Hunter \& Bailey 2015) and vascular tone (Ullian 1999, Dover et al. 2007, Hadoke et al. 2009), as well as heart rhythm and contractility (Lefer 1967, 1968, Penefsky \& Kahn 1971, Ouvrard-Pascaud et al. 2005, Cruz-Topete et al. 2016). Under pathological conditions, rapid corticosteroid release in response to hypothalamicpituitary-adrenal (HPA) axis activation is an early response to cardiovascular insult, including after myocardial infarction (MI). In the acute period, post-MI corticosteroids are cardioprotective and suppress the early inflammatory response to injury (Libby et al. 1973, Skyschally et al. 2004). However, sustained excessive glucocorticoid release from the adrenals, for example in Cushing's syndrome, is associated with detrimental cardiac outcomes, including myocardial ischaemia and hypertrophy, and in rare cases, with loss of cardiomyocytes and dilated cardiomyopathy (Peppa et al. 2009, Shibusawa et al. 2015, Frustaci et al. 2016). Chronic stress associates with cardiovascular disease (Kumari et al. 2011), as does pharmacological glucocorticoid treatment (Wei et al. 2004, Souverein et al. 2004).

Corticosteroids influence cell behaviour primarily through the intracellular activation of glucocorticoid http://jme.endocrinology-journals.org DOI: 10.1530/JME-16-0128
(C) 2017 The authors Published by Bioscientifica Ltd Printed in Great Britain
This work is licensed under a Creative Commons Attribution 3.0 Unported License. 
(GR) and mineralocorticoid (MR) receptors. In the heart, activation of both GR and MR has an impact on cardiac development, physiology and pathophysiology (reviewed in Oakley \& Cidlowski 2015 and Richardson et al. 2016). GR and MR are highly related and belong to the nuclear receptor family of transcriptional regulators (Biddie et al. 2010), although some corticosteroid actions may be mediated by non-classical signalling through cell-surface receptors (Mihailidou \& Funder 2005, Samarasinghe et al. 2012). The GR binds glucocorticoids with 10- to 30-fold lower affinity than the MR, but is relatively selective for glucocorticoid compared with mineralocorticoid binding (Mihailidou \& Funder 2005, Samarasinghe et al. 2012). The MR has high affinity for both mineralocorticoids and glucocorticoids, but as glucocorticoids typically circulate at levels 100-fold higher than those of mineralocorticoids, the MR is likely to be constitutively occupied by glucocorticoids even at daily nadir levels. Downstream signalling may differ depending on which ligand occupies the receptor and, depending on prevailing conditions, glucocorticoids can behave as agonists or antagonists at the MR (reviewed in Funder 2012). Access of mineralocorticoids to the MR depends on specific mechanisms that regulate the intracellular availability of adrenocorticosteroid hormones (Funder et al. 1988). These include the extent of protein binding in the plasma and in the heart itself (Bolton et al.2014, Schafer et al. 2015) and the activity of transporters that actively extrude steroids from the cell. However, glucocorticoids also undergo intracellular metabolism, and the capacity of individual cells to metabolise glucocorticoids is a critical factor in determining the extent (and indeed selectivity) of MR and GR activation (Funder et al. 1988, Odermatt \& Kratschmar 2012, Chapman et al. 2013a).

\section{1ß-HSD enzymes}

$11 \beta$-hydroxysteroid dehydrogenase $(11 \beta$-HSD) catalyses the intracellular interconversion of the glucocorticoids

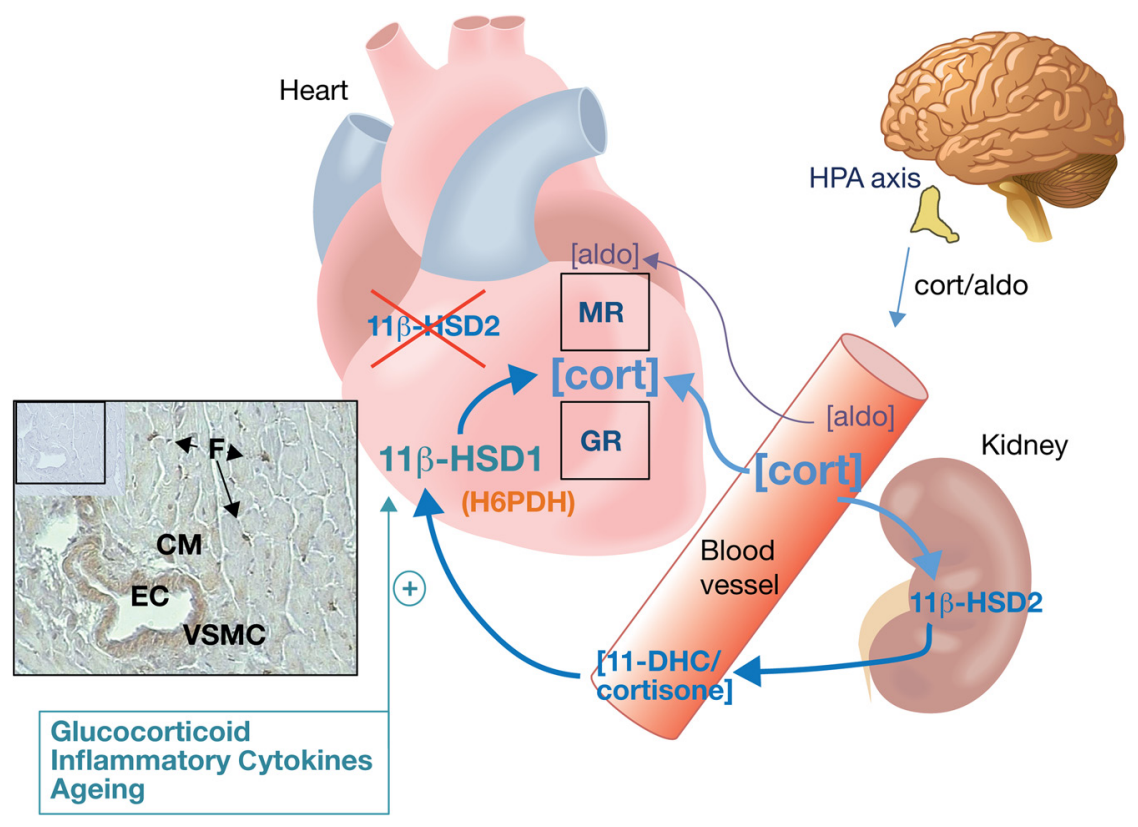

\section{Figure 1}

Adrenocorticosteroids, 11 $\beta$-HSD1 and the heart. Hypothalamic-pituitary-adrenal (HPA) axis-derived glucocorticoids (cortisol in man, corticosterone in rats and mice) and the mineralocorticoid - aldosterone - compete for binding to cardiac glucocorticoid (GR) and mineralocorticoid receptors (MR). Glucocorticoids are also regenerated within the heart from circulating inert metabolites (cortisone in man and 11-dehydrocorticosterone (11-DHC) in rats and mice) by $11 \beta$-hydroxysteroid dehydrogenase type 1 (11 $\beta$-HSD 1), when it is expressed alongside hexose-6-phosphate dehydrogenase (H6PDH). As the glucocorticoid concentration ([cort]) normally far exceeds that of aldosterone ([aldo]), GR and MR are usually occupied by glucocorticoids. $11 \beta$-hydroxysteroid dehydrogenase type 2 (11 -HSD2) inactivates glucocorticoids, but unlike other MR target tissues, there is normally little or no dehydrogenase activity in the heart. Inactivation of glucocorticoids by $11 \beta-H S D 2$ activity elsewhere in the body, largely in the kidney, generates the inert precursors that, on entering the circulation, become available for glucocorticoid regeneration and GR/MR activation in cells that express $11 \beta$-HSD1. In the healthy heart, 11ß-HSD1 immunoreactivity (inset panel) is localised to vascular smooth muscle (VSM), fibroblasts (F) and also cardiomyocytes (CM) in a fixed section from mouse left ventricle. The 11ß-HSD1 antibody is a sheep anti-mouse polyclonal generated in house (De Sousa Peixoto et al. 2008). Staining is notably absent in endothelial cells (EC) lining the vascular wall. A negative control of the same section generated using sheep IgG is shown in the inset panel. From S J McSweeney, PhD thesis, 2010 (McSweeney 2010). 11 $\beta$-HSD1 expression can be increased by glucocorticoids, by pro-inflammatory Cytokines and in ageing in other tissues and this is also likely to be the case in the heart.

http://jme.endocrinology-journals.org DOI: 10.1530/JME-16-0128
() 2017 The authors Printed in Great Britain
Published by Bioscientifica Ltd 
cortisol and corticosterone with their inert 11-keto forms (cortisone and 11-dehydrocorticosterone (11-DHC),

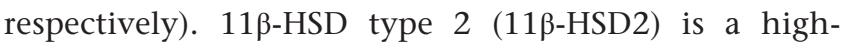
affinity (nanomolar KM), low-capacity NAD-dependent dehydrogenase (Albiston et al. 1994, Brown et al. 1996) that inactivates the glucocorticoids (Fig. 1). 11ß-HSD1 shares less than 30\% homology with 11 $\beta$-HSD2 (Lakshmi \& Monder 1988, Agarwal et al. 1989) and is more widely distributed than $11 \beta$-HSD2. Under normal conditions, it is co-expressed at the luminal border of the endoplasmic reticulum alongside hexose-6-phosphate dehydrogenase (H6PDH) (Atanasov et al. 2008) that provides the co-substrate NADPH (Bujalska et al. 2005). This drives the oxo-reductase activity of $11 \beta$-HSD1, re-activating the glucocorticoids (Atanasov et al. 2004, Bujalska et al. 2005, Lavery et al. 2006, Chapman et al. 2013a) (Fig. 1). 11 $\beta$-HSD1 has low affinity for glucocorticoids (micromolar KM) relative to $11 \beta-\mathrm{HSD} 2$, but where H6PDH is genetically deleted (Lavery et al. 2006) or where cells are disrupted so that NADPH cannot be generated in close proximity to $11 \beta$-HSD 1 , it switches from predominantly oxo-reductase to dehydrogenase activity and this inactivates rather than regenerates glucocorticoids (Atanasov et al. 2004). Activity of 11ß-HSD1 (largely in the liver) and 11 -HSD2 (largely in the kidney) determines active and keto-isoform concentrations in the systemic circulation, but the variability in the activity of $11 \beta-\mathrm{HSD}$ enzymes at the level of target cells adds a cell-specific dimension to the control of steroid action (Chapman et al. 2013a). To date, there has been relatively little focus on the capacity of the myocardium or of its component cells to metabolise corticosteroids.

\section{1/-HSD2 and MR activation in the heart}

In mineralocorticoid target tissues, $11 \beta-H S D 2$ is expressed alongside the MR, where its activity reduces the availability of glucocorticoid, permitting aldosterone to compete for binding to the MR (Edwards et al. 1988, Funder et al. 1988). The clinical efficacy of MR antagonists after MI (Pitt et al. 2003) and in heart failure (Pitt et al. 1999, Zannad et al. 2011,2012 ) are attributed, at least in part, to blockade of MR activation in the heart. A recent preclinical study in adrenalectomised rats has shown that mineralocorticoids regulate cardiac electrical function through the activation of MR (Cruz-Topete et al. 2016). However, the weight of evidence suggests that there is normally little or no 11ß-HSD2 activity in the heart (Walker et al. 1991, Whorwood et al. 1992), except perhaps in vascular endothelium (Walker et al. 1991, Smith et al. 1996). This was confirmed in a recent in vivo study on patients undergoing diagnostic coronary angiography that failed to find any evidence for inactivation of the stable isotope tracer 9,11,12,12-[2H]4-cortisol across the human heart (Iqbal et al. 2014). Furthermore, infusion of the MR antagonist canrenoate in the same patients resulted in the elevation of cortisol collected from the coronary sinus. These data support the view that the cardiac MR is normally occupied by glucocorticoid, rather than by aldosterone. However, this situation may change in pathological conditions, including hypoxia (Klusonova et al. 2009), in which there is evidence for enhancement of $11 \beta$-HSD2 activity and expression (Chai et al. 2010, Chapman et al. 2013a), that may allow aldosterone to compete for binding to the MR. Selective overexpression of $11 \beta$-HSD2 in cardiomyocytes leads to MR-dependent hypertrophy and fibrosis in mice (Qin et al. 2003), showing potential for a role in cardiac pathology. Global 11 -HSD2 knockout mice have cardiac hypertrophy and fibrosis but, as these mice are also hypertensive (Kotelevtsev et al. 1999), any phenotype that is specifically due to lack of $11 \beta$-HSD 2 in the heart has proved impossible to dissect. Generation of mice with targeted 11 $\beta$-HSD2 deletion in cardiomyocytes and other cardiac cells would provide a more definitive answer regarding the role of dehydrogenase activity in cardiac physiology and pathology.

\section{Glucocorticoid regeneration by $11 \beta-H S D 1$ in the heart}

$11 \beta$-HSD 1 is more widely expressed in the body than $11 \beta$-HSD2, but tissue expression of $11 \beta-\mathrm{HSD} 1$ is often reported to be low. This is also the case in the heart or at least in whole ventricular homogenates (Walker et al. 1991, White et al. 2016). However, immunoreactive 11ß-HSD1 can be localised to cardiomyocytes, to interstitial and adventitial fibroblasts (Brereton et al. 2001) and to vascular smooth muscle in murine heart (Fig. 1) (McSweeney 2010). We have found that targeted deletion of 11ß-HSD1 in cardiomyocytes and vascular smooth muscle cells leads to a significant reduction in $H s d 11 b 1$ gene expression in the mouse heart, confirming its expression in these cells (White et al. 2016). Although endothelial cells in culture are reported to have 11ß-HSD1 activity (Brem et al. 1998), previous studies have concluded that the $11 \beta$-HSD enzyme in aortic endothelial cells is primarily a dehydrogenase, with oxo-reductase activity limited to the smooth muscle cell compartment of the vascular wall (Walker et al. 1991, Dover et al. 2007). Immunostaining suggests that this is also the case in the coronary vessels

Published by Bioscientifica Ltd. 
A

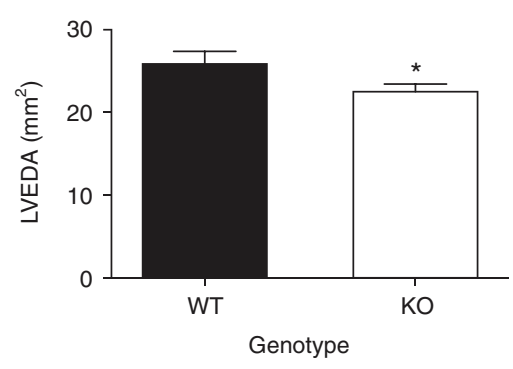

B
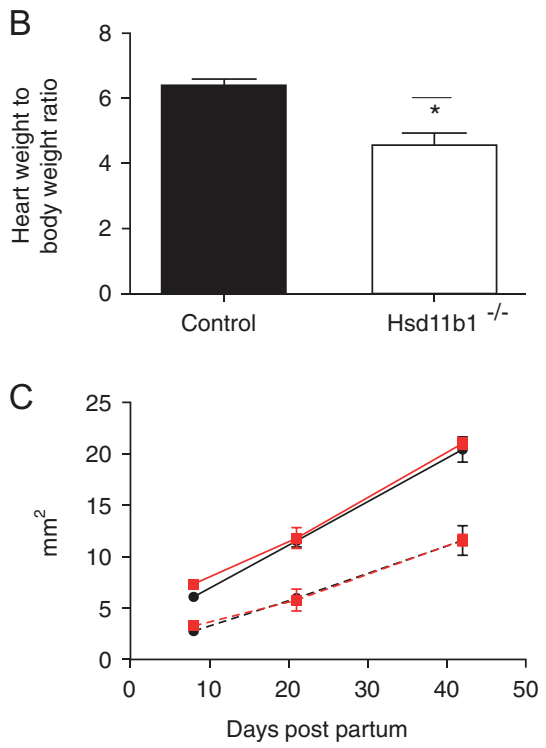

D

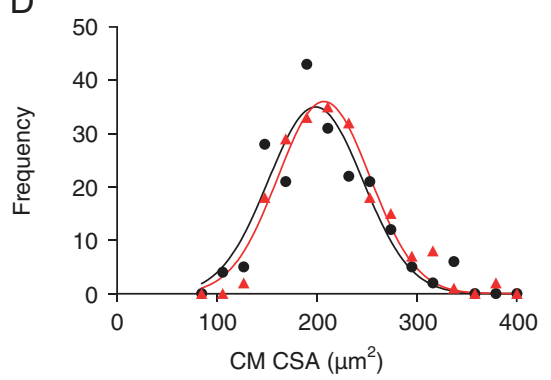

E
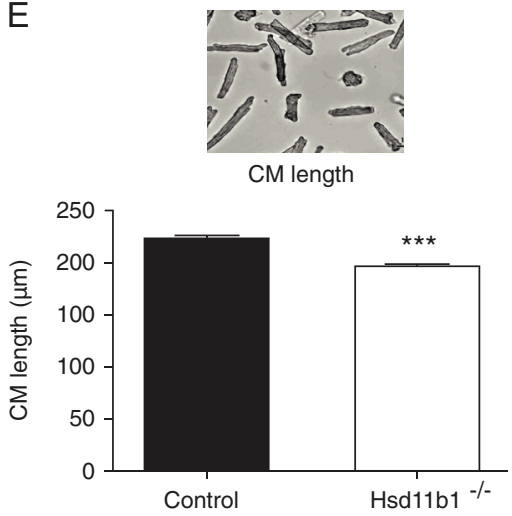

Figure 2

Hearts from adult mice with global $11 \beta$-HSD1 deficiency are hypomorphic and have shorter cardiomyocytes. Ultrasound analysis $(A)$ reveals a significant reduction in left ventricular dimensions in 12-week-old Hsd11b1-/- (open bars) compared with control wild-type mice (filled bars). Reduction in heart size was confirmed when post-mortem heart weight was compared with body weight (B). LV dimensions (left ventricular end-diastolic area, solid red (Hsd11b1-/-) and black (control wild type), and left ventricular end-systolic area, hatched red (Hsd11 b1 ${ }^{-/-}$) and black (control wild type)) were not influenced by the loss of $11 \beta$-HSD 1 from late gestation until 6 weeks of age (C). In adult hearts, there was no effect of $11 \beta$-HSD 1 deficiency (red) on the distribution of cardiomyocyte crosssectional area (D), but the length of individual

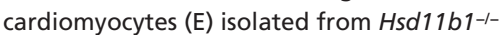
hearts was significantly less than that isolated from control wild-type hearts (black). ${ }^{\star} P<0.05$, $* * * P<0.005, n=5-8$.
(Fig. 1). Fibroblasts are among the most abundant cells in the heart, and transcriptomic analysis has revealed that expression of $H s d 11 b 1$ is high in cardiac fibroblasts relative to fibroblasts elsewhere in the body (Furtado et al. 2014), consistent with a potentially important role here.

Myocardial expression of H6PDH (Brereton et al. 2001, Gomez-Sanchez et al. 2008), and H6PDH immunoreactivity in cells identified as fibrocytes (GomezSanchez et al. 2008), suggests that NADPH will be available to support oxo-reductase activity in the heart. However, conversion of 11-DHC to corticosterone is comparatively low in whole ventricular homogenate from mice and rats (Walker et al. 1991, Sheppard \& Autelitano 2002). Similarly, although HSD11B1 mRNA is present in human heart (Chai et al. 2010), cortisol is not significantly regenerated from cortisone infused in vivo into the hearts of patients undergoing elective coronary angiography (Iqbal et al. 2014). Thus, although there is plentiful evidence that myocardial cells express $11 \beta$-HSD1, reactivation of glucocorticoid is apparently limited under physiological conditions. Nevertheless, our phenotyping studies in mice with genetically induced 11 $\beta$-HSD1 deficiency show that $11 \beta$-HSD1 activity has a role in determining normal postnatal growth of the heart (Fig. 2 and below), as well as $\mathrm{Ca}^{2+}$ handling and diastolic function (White 2016).

\section{$11 \beta-H S D 1$ in postnatal growth of the myocardium}

GR activation during a prenatal surge in plasma glucocorticoid is essential for the structural and functional maturation of the heart before birth (Rog-Zielinska et al. 2014 , 2015), and consequently, genetic deletion of GR from the heart and smooth muscle results in increased perinatal mortality (Rog-Zielinska et al. 2013, 2014). $11 \beta$-HSD1 is not expressed to any extent in the mouse heart in the prenatal period (Speirs et al. 2004), and neither global (Kotelevtsev et al. 1997) nor cardiomyocyte and vascular smooth muscle cell-specific (White et al. 2016) deletion of $H s d 11 b 1$ has any influence on perinatal mortality. However, a role for $11 \beta$-HSD1 in the maturation of the postnatal heart is indicated by our observation that hearts from adult mice with global deficiency of 11ß-HSD1 are smaller than those of wild-type mice (McSweeney 2010, McSweeney et al. 2010; Fig. 2A). Cardiomyocyte GR activation in the neonatal period promotes the switch

Published by Bioscientifica Ltd 
from proliferative to hypertrophic growth (Richardson et al. 2016). MR activation in the same period promotes proliferation (Feng et al. 2013). Proliferative neonatal cardiomyocytes can reactivate glucocorticoids through $11 \beta$-HSD1 oxo-reductase activity during the period that they retain proliferative capacity (Lister et al. 2006). However, the hearts of globally $11 \beta$-HSD1-deficient mice have normal ventricular dimensions from E18.5 to at least P40 (Fig. 2B). Mice with targeted deletion of 11ß-HSD1 in cardiomyocytes and vascular smooth muscle also have phenotypically normal hearts (White et al. 2016). Therefore, loss of cardiomyocyte corticosteroid receptor activation in the perinatal period does not account for the smaller size of hearts in adult 11/-HSD1 mice. Interestingly, further analysis revealed that although cardiomyocyte cross-sectional area is normal in adult hearts of $11 \beta$-HSD1deficient mice (Fig. 2C), cardiomyocyte length is reduced (Fig. 2D; White 2016). Cardiomyocytes are influenced by physical interactions and paracrine signalling from other cells in their environment. Blood volume and blood pressure are not modified in mice with global 11/-HSD1 deficiency, so altered in vivo haemodynamic stress is not likely to underlie the reduction in cardiomyocyte length (White 2016). Further investigation is required to find whether the loss of 11ß-HSD1 in other myocardial cells, for example, resident macrophages or fibroblasts can indirectly influence cardiomyocyte size during postnatal growth. In terms of clinical relevance, it is notable that a single nucleotide polymorphism in the HSD11B1 gene is also associated with reduced left ventricular mass (Rahman et al. 2011), although the underlying mechanism was not investigated.

\section{1/-HSD1 and myocardial pathology}

Although cellular 11 $\beta$-HSD1 expression and activity may normally be low in the heart, both can change rapidly in response to external stimuli (reviewed in Chapman et al. 2013b). Glucocorticoid itself promotes 11ß-HSD1 expression (Sai et al. 2008, Morgan et al. 2014), and there is good evidence that $11 \beta$-HSD1 is the major regulator of the tissue-specific effects of circulating glucocorticoid excess (Morgan et al. 2014). The pro-inflammatory cytokines IL- 1 and TNF- $\alpha$ are also key activators of $11 \beta$-HSD1 gene expression, notably in fibroblasts (Hardy et al. 2006, Stegk et al. 2009, Ahasan et al. 2012, Chapman et al. 2013b, Esteves et al. 2014). These cytokines can act alone or synergistically with glucocorticoid (Kaur et al. 2010, Ahasan etal.2012), to effect an increase in the capacity for intracellular glucocorticoid regeneration by $11 \beta$-HSD1. After trauma or injury, pro-inflammatory conditions that potently increase HPA axis activity (and thereby plasma 11-DHC/cortisone levels (Harris et al. 2001)), increased $11 \beta$-HSD1 activity is likely to be a significant contributor to intracellular glucocorticoid levels and thus GR and MR activation. The generation of mice lacking 11ß-HSD1 (Kotelevtsev et al. 1997, Holmes et al. 2001) and more recently, the development of specific 11ß-HSD1 inhibitors (Hughes et al. 2008, Wheelan et al. 2014, Sooy et al. 2015), have provided the opportunity to identify such roles for amplification of intracellular glucocorticoid signalling by 11ß-HSD1 in cardiac pathophysiology.

\section{1/-HSD1, MI and heart failure}

MI occurs most commonly after the formation of a clot on a ruptured atherosclerotic plaque, leading to ischaemic cardiomyocyte death in the area served by the affected coronary artery. As the adult heart has only very limited ability to regenerate, MI is followed by a period of wound healing that results in the formation of a scar to maintain myocardial integrity (Video 1; Frangogiannis 2014). The extent of cardiomyocyte loss during ischaemia and expansion of injury during infarct repair are critical determinants of subsequent structural remodelling and functional deterioration leading to heart failure (Di Bella et al. 2013).

\section{Video 1}

Coronal view of mouse heart collected 7 days after induction of myocardial infarction and imaged by optical projection tomography, as we have described in (Zhao et al. 2015). Progressive optical sectioning through the heart reveals the extensive, thinned infarct area of the left ventricle. In 11 $\beta$-HSD 1 deficient mice the length of the infarcted area is reduced and the ventricle wall is less thinned (McSweeney et al. 2010, White 2016). View Video 1 at http://movie-usa.glencoesoftware.com/video/10.1530/ JME-16-0128/video-1

In a preclinical model of atherosclerosis in ApoEdeficient mice, pharmacological inhibition (HermanowskiVosatka et al. 2005), or genetic ablation (Garcia et al. 2013, Kipari et al. 2013), of $11 \beta$-HSD1 is associated with reduction in plaque size independently of changes in lipid availability. Plaque size reduction in ApoE/11ßHSD1 double knockout mice was attributed to loss of 11ß-HSD1 in bone marrow-derived cells (Kipari et al. 2013). These cells are recruited to the arterial wall during plaque formation, where they accumulate lipid and contribute to the determination of plaque stability. Neutrophils, monocyte/macrophages and T cells express 11 $\beta$-HSD1

Published by Bioscientifica Ltd 
(Zhang \& Daynes 2007, Zhang et al. 2005), and expression is increased during their mobilisation and activation (reviewed in Chapman et al. 2013b). Intracellular generation of glucocorticoid in monocyte/macrophages and neutrophils regulates their recruitment to sites of inflammation (Tiganescu et al. 2011), phagocytic potential (Speirs et al. 2004) and the release of pro-inflammatory molecules (Zhang \& Daynes 2007). 11 $\beta$-HSD1 inhibition may therefore be of therapeutic benefit in preventing the development of complex plaques that are vulnerable to rupture causing $\mathrm{MI}$.

Mice with global deficiency of $11 \beta$-HSD 1 also have reduced structural and functional remodelling after MI, induced by coronary artery ligation, and do not go on to develop heart failure (McSweeney et al. 2010, White et al. 2016). Thus, 11 $\beta$-HSD1 availability has an impact not only on the development of coronary artery disease that leads to MI but also on the response of the myocardium after MI. Increased plasma corticosterone, derived from HPA axis activation in the immediate post-infarct period, reduces cardiomyocyte death and infarct size and there is evidence supporting roles for both GR (Hafezi-Moghadam et al. 2002) and MR (Mihailidou et al. 2009, Fraccarollo et al. 2011 ) in determining this outcome. However, in 11 $\beta$-HSD1deficient mice, plasma corticosterone is increased to the same extent after MI as in wild-type mice and infarct injury is unchanged (McSweeney et al. 2010). Therefore, differences in the immediate response to MI do not underlie the subsequent reduction in cardiac remodelling in the absence of $11 \beta$-HSD1. However, peri-infarct angiogenesis is enhanced in 11 -HSD1-deficient mice during repair (Small et al. 2005), and this is associated with reduced infarct expansion in this period and with eventual scar size (McSweeney et al. 2010). Glucocorticoids suppress angiogenesis, and prevention of intracellular glucocorticoid regeneration in 11 $\beta$-HSD1-deficient mice promotes angiogenesis in different in vitro and in vivo experimental models (Small et al. 2005). Smooth muscle cells are the main site of intravascular $11 \beta$-HSD1 activity (Hadoke et al. 2013), but targeted deletion of Hsd11b1 in cardiomyocytes and vascular smooth muscle cells failed to enhance angiogenesis or improve outcome after MI (White et al. 2016). Engagement of extra-vascular pro-angiogenic mechanisms is therefore indicated. Increased angiogenesis in 11 $\beta$-HSD1-deficient mice after MI is preceded by increased content of reparative 'M2' macrophages during the proliferative phase of wound healing (McSweeney et al. 2010). These 'M2' macrophages are essential for infarct repair (Shiraishi et al. 2016) and can release growth factors and pro-angiogenic mediators that increase neovascularisation during wound healing, as well as for promoting the formation of a mature collagen scar. Enhancement of macrophage polarisation in mice lacking $11 \beta$-HSD1 is therefore likely to be a key mechanism underlying improved outcome after MI (Fig. 3). Increased 'M2' polarisation of macrophages could occur due to loss of $11 \beta$-HSD1 in the inflammatory cells themselves, as proposed in atherosclerosis (Kipari et al. 2013), resulting in the modification of inflammatory cell recruitment and phenotype (Frangogiannis 2014).

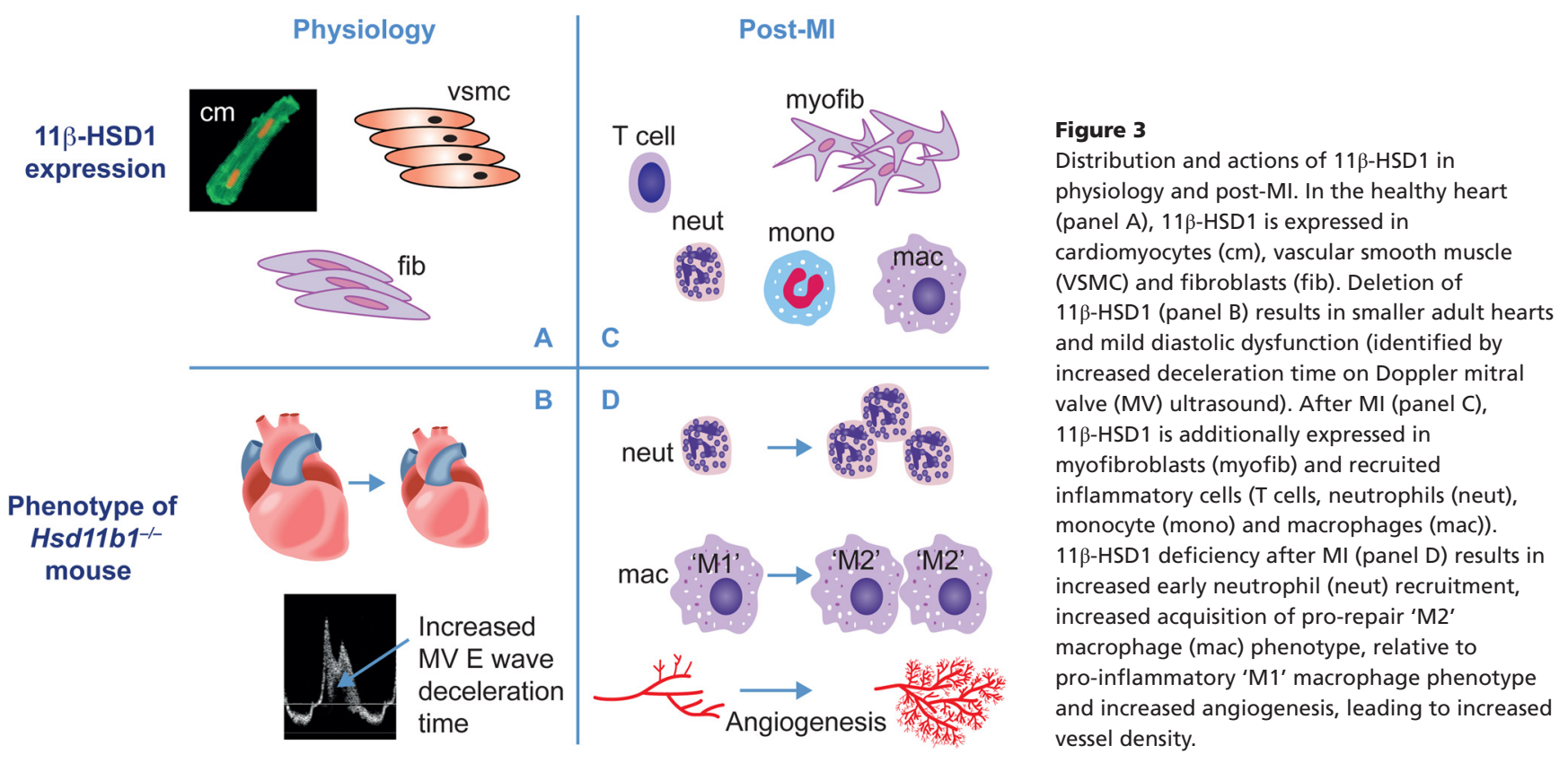


Macrophage MR knockout (Usher et al. 2010), or GR activation (Gratchev et al. 2008), results in polarisation towards an 'M2' phenotype, and MR antagonists increase 'M2' macrophage polarisation in the heart when given after MI (Fraccarollo et al. 2008). Loss of glucocorticoid regenerative capacity in macrophages could therefore conceivably underlie changes in the activation status by preventing the activation of MR. However, promotion of peri-infarct angiogenesis after MI is enhanced when GR is blocked (Small et al. 2005), supporting a more indirect mechanism that involves GR, rather than MR activation.

Neutrophil recruitment is increased in the hearts of 11 $\beta$-HSD1-deficient mice after the induction of MI (McSweeney et al. 2010) (Fig. 3). This results at least in part from loss of 11 $\beta$-HSD1 in neutrophils themselves, where its activity restrains recruitment to inflamed tissues through modulation of adhesion molecule availability at the cell surface (Cavalcanti et al. 2006, Tiganescu et al. 2011, Coutinho et al. 2016). Loss of 11ß-HSD1 activity in the heart itself is also likely to contribute. Expression of neutrophil chemoattractants, including CXCL5/LIX (Smith \& Herschman 1995), IL-6 (Hardy et al. 2006) and CXCL2/MIP2 $\alpha$ (Uhlenhaut et al. 2013) is repressed by glucocorticoid, and these chemoattractants are expressed by cells in the heart that express $11 \beta-H S D 1$, including fibroblasts. Mast cell degranulation after myocardial injury also enhances neutrophil recruitment, and as degranulation is increased in the absence of 11 $\beta$-HSD1 (Coutinho et al. 2013), these cells may also play a role in increasing neutrophil recruitment in 11ß-HSD1-deficient mice. In the post-infarct heart, neutrophils phagocytose necrotic myocytes and break down the intracellular matrix during the initial inflammatory phase of repair. However, they also promote the transition to resolution by releasing gelatinase-associated lipocalin (Horckmans et al. 2016). Efferocytosis, or macrophage engulfment of apoptotic cells, including neutrophils (Wan et al. 2013), will also enhance the acquisition of an 'M2' phenotype. Early enhancement of neutrophil recruitment may thus be an essential prerequisite for the promotion of repair in the mice lacking 11 $\beta$-HSD1.

Several lines of evidence point to cardiac fibroblasts, particularly their high expression of $11 \beta$-HSD1 (Furtado et al. 2014), as a key site for intracellular regeneration of glucocorticoid in the healing myocardial infarct (Chen \& Frangogiannis 2013). 11ß-HSD1 activity in stromal cells elsewhere, including synovial fibroblasts, is promoted by the action of corticosteroids and inflammatory mediators (Hardy et al. 2006, Ahasan et al. 2012). In the skin, 11ß-HSD1 is active in dermal fibroblasts (Tiganescu et al. 2011) and global 11ß-HSD1 knockout or pharmacological inhibition promotes skin wound healing (Tiganescu et al. 2013). Fibroblasts are abundant in the heart and have multiple potential roles during myocardial inflammation and repair that follows MI (Porter \& Turner 2009). In addition to the production of collagen and other matrix proteins that determine scar integrity, they secrete molecules, including cytokines, prostaglandins (Shinde \& Frangogiannis 2014, Fernando et al. 2015, Turner 2016) and microRNA (Fang \& Yeh 2015), capable of regulating inflammation (Porter \& Turner 2009, Chen \& Frangogiannis 2013, van Nieuwenhoven \& Turner 2013), Treg recruitment (Frangogiannis 2014), angiogenesis (Newman etal. 2011), cardiogenesis (Furtado et al. 2014) and hypertrophy (Abonnenc et al. 2013, Cartledge et al. 2015). The role of cardiac fibroblast $11 \beta$-HSD1 in regulating the cellular secretome and on the response to MI and other pathological challenges merits further investigation.

\section{Therapeutic potential of 11/-HSD1 inhibition in myocardial disease}

Pharmacological inhibitors of $11 \beta$-HSD1 have already been developed for use in metabolic disease and for prevention of cognitive decline (Anderson \& Walker 2013, Sooy et al. 2015). Survival after MI is increasing, thanks to prompt and efficient intervention to restore perfusion to the ischaemic myocardium (BHF Heart Stats, 2015). However, patients survive with damage to their myocardium that spreads to the peri-infarct area during wound healing. Thus, although the introduction of coronary revascularisation has been associated with a reduction in early post-MI deaths, there has been an increase in the 5 -year incidence of HF (Velagaleti et al. 2008). Preclinical data are highly supportive of the therapeutic potential of $11 \beta$-HSD1 inhibitors in the prevention of atherosclerosis (Hermanowski-Vosatka et al. 2005, Garcia et al. 2013, Kipari et al. 2013), as well as acutely following MI, to prevent the infarct expansion that promotes the development of heart failure (McSweeney et al. 2010, White et al. 2016). Ventricular hypertrophy is a feature of the adaptive ventricular remodelling that follows $\mathrm{MI}$ and in pressure overload associated with hypertension. Gordon and

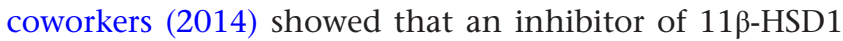
was able to reverse established hypertrophy and associated dysfunction in a mouse model of perfusion deficitinduced cardiac remodelling. Interestingly, this outcome was independent of any influence on neovascularisation or perfusion. Inhibition of $11 \beta$-HSD1 may therefore

Published by Bioscientifica Ltd 
have additional benefits on post-MI remodelling beyond the prevention of infarct expansion. In clinical trials of $11 \beta$-HSD1 inhibitors in diabetes, improvement in blood glucose and other metabolic end points failed to reach significance when compared with existing therapies, but the evidence for a modest benefit was highly consistent (Anderson \& Walker 2013). Such benefits in metabolic outcomes are likely to be advantageous in patients with cardiovascular disease. Together, these data demonstrate the potential for 'repurposing' of 11ß-HSD1 inhibitors already developed for clinical use in other therapeutic areas. None of the trials of these inhibitors in diabetes have raised any question on the effectiveness of target engagement or on toxicology. Improved understanding of the cellular mechanisms through which 11ß-HSD1 inactivation enhances angiogenesis prevents infarct expansion, and adverse ventricular remodelling will help to justify the clinical development of $11 \beta$-HSD1 inhibitors for MI therapy, as well as providing biomarkers to monitor the effects of 11ß-HSD1 inhibition.

MR antagonists are already used effectively in the treatment of heart failure (Pitt etal. 1999, Zannad etal.2011, 2012), by preventing MR activation in cardiomyocytes (Fraccarollo et al. 2011) and in macrophages (Fraccarollo et al. 2008). Preclinical studies have revealed the potential benefits of blocking GR in cardiovascular disease (Small et al. 2005, Oakley \& Cidlowski 2015, Richardson et al. 2016), but essential physiological roles of GR activation preclude the use of GR antagonists in vivo. With their distinct profile of action, 11 -HSD1 inhibitors offer an alternative means of regulating GR and MR activation in specific cells. 11 $\beta$-HSD1 inhibitors might provide an alternative to MR antagonists in patients who do not tolerate the effects of $\mathrm{MR}$ antagonism on $\mathrm{K}^{+}$handling (Pitt et al. 2008). Alternatively, they may have additional or complementary benefits when combined with MR antagonists, and this should be tested in models of cardiovascular disease.

In this review, we have considered $11 \beta$-HSD1 in the context of its capacity for intracellular regeneration of active glucocorticoids from inert metabolites. However, $11 \beta$-HSD1 has other actions that may contribute to the physiological and pathophysiological outcomes reported previously. 11ß-HSD1 is a multifunctional carbonyl reductase that also converts 11- and 7-oxosterols into the respective 7-hydroxylated forms and also catalyses the reduction of non-steroidal xenobiotics (Mitic et al. 2013b, Odermatt \& Klusonova 2015). Studies with selective inhibitors and genetically modified mice provide further evidence for the effects of $11 \beta$-HSD 1 in the regulation of cellular cholesterol flux and on bile acid homeostasis (Mitic et al. 2013a). Oxysterols influence vascular function (Mitic et al. 2013a), and modulation of genes involved in cellular cholesterol flux is associated with disease severity in patients after MI (Suresh et al. 2014). These mechanisms may therefore be engaged alongside prevention of intracellular glucocorticoid regeneration when $11 \beta-H S D 1$ is genetically depleted or inhibited and could contribute to any beneficial effects of drug intervention in cardiovascular pathology.

\section{Conclusion}

Studies over the past three decades have demonstrated roles for the 11 $\beta$-HSD enzymes in metabolic, neurological and inflammatory diseases, but roles in the heart have been relatively unexplored. Recent studies have shown that $11 \beta-H S D 1$ is expressed in myocardial cells, including notably cardiac fibroblasts. Global 11 $\beta$-HSD1 deficiency has effects on cardiac growth and physiological function that are more subtle than those associated with GR deletion (Oakley \& Cidlowski 2015, Richardson et al. 2016), or adrenalectomy (Cruz-Topete et al. 2016), but nevertheless of physiological relevance. Importantly, genetic or pharmacological depletion of $11 \beta$-HSD1 also prevents adverse cardiac remodelling and the development of heart failure after MI (McSweeney et al. 2010, Gordon et al. 2014, White et al. 2016). In the skin, 11ß-HSD1 expression is increased during ageing (Tiganescu et al. 2011) and $11 \beta$-HSD1 inhibition prevents age-induced structural defects (Tiganescu et al. 2013). If 11ß-HSD1 expression is similarly increased in the heart, the influence of $11 \beta$-HSD1 on myocardial physiology and pathophysiology is likely to be even more pronounced in the aged heart. Novel mass spectrometry imaging has recently permitted accurate localisation of 11ß-HSD1 'intracrinology' in sections of mouse adrenal gland and brain (Cobice et al. 2013). Application of mass spectrometry imaging to the heart will be of significant value to understand cellular $11 \beta$-HSD1 activity and how it is changed in ageing and disease. Whether the key intracellular mechanisms of $11 \beta$-HSD1 are dependent or independent of glucocorticoid regeneration, preclinical studies have started to reveal novel therapeutic potential for drugs that inhibit $11 \beta$-HSD1. Given that $11 \beta$-HSD1 expression and activity can be rapidly increased by inflammatory mediators and by glucocorticoids, there are likely to be further applications for these drugs in cardiovascular disease,

Published by Bioscientifica Ltd. 
as well as in preventing the deterioration of cardiac function associated with chronic stress, Cushing's disease and glucocorticoid therapy (Souverein et al. 2004, Wei et al. 2004, Peppa et al. 2009, Kumari et al. 2011, Shibusawa et al. 2015, Frustaci et al. 2016).

\section{Declaration of interest}

The authors declare that there is no conflict of interest that could be perceived as prejudicing the impartiality of this review.

\section{Funding}

Work in the authors' lab is supported by the British Heart Foundation (FS/09/053 and FS/12/30002), the Wellcome Trust (083184) and the British Heart Foundation Centre of Research Excellence.

\section{References}

Abonnenc M, Nabeebaccus AA, Mayr U, Barallobre-Barreiro J, Dong X, Cuello F, Sur S, Drozdov I, Langley SR, Lu R, et al. 2013 Extracellular matrix secretion by cardiac fibroblasts: role of microRNA-29b and microRNA-30c. Circulation Research 113 1138-1147. (doi:10.1161/ CIRCRESAHA.113.302400)

Agarwal AK, Monder C, Eckstein B \& White PC 1989 Cloning and expression of rat cDNA encoding corticosteroid 11 betadehydrogenase. Journal of Biological Chemistry 264 18939-18943.

Ahasan MM, Hardy R, Jones C, Kaur K, Nanus D, Juarez M, Morgan SA, Hassan-Smith Z, Benezech C, Caamano JH, et al. 2012 Inflammatory regulation of glucocorticoid metabolism in mesenchymal stromal cells. Arthritis and Rheumatism 64 2404-2413. (doi:10.1002/art.34414)

Albiston AL, Obeyesekere VR, Smith RE \& Krozowski ZS 1994 Cloning and tissue distribution of the human 11 beta-hydroxysteroid dehydrogenase type 2 enzyme. Molecular and Cellular Endocrinology 105 R11-R17. (doi:10.1016/0303-7207(94)90176-7)

Anderson A \& Walker BR 2013 11beta-HSD1 inhibitors for the treatment of type 2 diabetes and cardiovascular disease. Drugs 73 1385-1393. (doi:10.1007/s40265-013-0112-5)

Atanasov AG, Nashev LG, Schweizer RA, Frick C \& Odermatt A 2004 Hexose-6-phosphate dehydrogenase determines the reaction direction of 11beta-hydroxysteroid dehydrogenase type 1 as an oxoreductase. FEBS Letters 571 129-133. (doi:10.1016/j.febslet.2004.06.065)

Atanasov AG, Nashev LG, Gelman L, Legeza B, Sack R, Portmann R \& Odermatt A 2008 Direct protein-protein interaction of 11betahydroxysteroid dehydrogenase type 1 and hexose-6-phosphate dehydrogenase in the endoplasmic reticulum lumen. Biochimica et Biophysica Acta 1783 1536-1543. (doi:10.1016/j.bbamcr.2008.03.001)

Biddie SC, John S \& Hager GL 2010 Genome-wide mechanisms of nuclear receptor action. Trends in Endocrinology and Metabolism 21 3-9. (doi:10.1016/j.tem.2009.08.006)

Bolton JL, Hayward C, Direk N, Lewis JG, Hammond GL, Hill LA, Anderson A, Huffman J, Wilson JF, Campbell H, et al. 2014 Genome wide association identifies common variants at the SERPINA6/ SERPINA1 locus influencing plasma cortisol and corticosteroid binding globulin. PLoS Genetics 10 e1004474. (doi:10.1371/journal. pgen.1004474)

Brem AS, Bina RB, King TC \& Morris DJ 1998 Localization of 2 11beta-OH steroid dehydrogenase isoforms in aortic endothelial cells. Hypertension 31 459-462. (doi:10.1161/01.HYP.31.1.459)

Brereton PS, Van Driel RR, Suhaimi F, Koyama K, Dilley R \& Krozowski Z 2001 Light and electron microscopy localization of the 11beta- hydroxysteroid dehydrogenase type I enzyme in the rat. Endocrinology 142 1644-1651. (doi:10.1210/en.142.4.1644)

Brown RW, Chapman KE, Murad P, Edwards CR \& Seckl JR 1996 Purification of 11 beta-hydroxysteroid dehydrogenase type 2 from human placenta utilizing a novel affinity labelling technique. Biochemical Journal 313 997-1005. (doi:10.1042/bj3130997)

Bujalska IJ, Draper N, Michailidou Z, Tomlinson JW, White PC, Chapman KE, Walker EA \& Stewart PM 2005 Hexose-6-phosphate dehydrogenase confers oxo-reductase activity upon 11 betahydroxysteroid dehydrogenase type 1. Journal of Molecular Endocrinology 34 675-684. (doi:10.1677/jme.1.01718)

Cartledge JE, Kane C, Dias P, Tesfom M, Clarke L, Mckee B, Al Ayoubi S, Chester A, Yacoub MH, Camelliti P, et al. 2015 Functional crosstalk between cardiac fibroblasts and adult cardiomyocytes by soluble mediators. Cardiovascular Research 105 260-270. (doi:10.1093/cvr/ cvu264)

Cavalcanti DM, Lotufo CM, Borelli P, Tavassi AM, Pereira AL, Markus RP \& Farsky SH 2006 Adrenal deficiency alters mechanisms of neutrophil mobilization. Molecular and Cellular Endocrinology 249 32-39. (doi:10.1016/j.mce.2006.01.007)

Chai W, Hofland J, Jansen PM, Garrelds IM, De Vries R, Van Den Bogaerdt AJ, Feelders RA, De Jong FH \& Danser AH 2010 Steroidogenesis vs. steroid uptake in the heart: do corticosteroids mediate effects via cardiac mineralocorticoid receptors? Journal of Hypertension 28 1044-1053. (doi:10.1097/ hjh.0b013e328335c381)

Chapman K, Holmes M \& Seckl J 2013a 11beta-hydroxysteroid dehydrogenases: intracellular gate-keepers of tissue glucocorticoid action. Physiological Review 93 1139-1206. (doi:10.1152/ physrev.00020.2012)

Chapman KE, Coutinho AE, Zhang Z, Kipari T, Savill JS \& Seckl JR $2013 b$ Changing glucocorticoid action: 11beta-hydroxysteroid dehydrogenase type 1 in acute and chronic inflammation. Journal of Steroid Biochemistry and Molecular Biology 137 82-92. (doi:10.1016/j. jsbmb.2013.02.002)

Chen W \& Frangogiannis NG 2013 Fibroblasts in post-infarction inflammation and cardiac repair. Biochim et Biophysica Acta 1833 945-953. (doi:10.1016/j.bbamcr.2012.08.023)

Cobice DF, Mackay CL, Goodwin RJ, Mcbride A, Langridge-Smith PR, Webster SP, Walker BR \& Andrew R 2013 Mass spectrometry imaging for dissecting steroid intracrinology within target tissues. Analytical Chemistry 85 11576-11584. (doi:10.1021/ac402777k)

Coutinho AE, Brown JK, Yang F, Brownstein DG, Gray M, Seckl JR, Savill JS \& Chapman KE 2013 Mast cells express 11betahydroxysteroid dehydrogenase type 1: a role in restraining mast cell degranulation. PLOS ONE 8 e54640. (doi:10.1371/journal. pone.0054640)

Coutinho AE, Kipari TM, Zhang Z, Esteves CL, Lucas CD, Gilmour JS Webster SP, Walker BR, Hughes J, Savill JS, et al. 2016 11betahydroxysteroid dehydrogenase type 1 is expressed in neutrophils and restrains an inflammatory response in male mice. Endocrinology 157 2928-2936. (doi:10.1210/en.2016-1118)

Cruz-Topete D, Myers PH, Foley JF, Willis MS \& Cidlowski JA 2016 Corticosteroids are essential for maintaining cardiovascular function in male mice. Endocrinology 157 2759-2771. (doi:10.1210/en.20151604)

De Sousa Peixoto RA, Turban S, Battle JH, Chapman KE, Seckl JR \& Morton NM 2008 Preadipocyte 11beta-hydroxysteroid dehydrogenase type 1 is a keto-reductase and contributes to dietinduced visceral obesity in vivo. Endocrinology 149 1861-1868. (doi:10.1210/en.2007-1028)

Di Bella G, Siciliano V, Aquaro GD, Molinaro S, Lombardi M, Carerj S, Landi P, Rovai D \& Pingitore A 2013 Scar extent, left ventricular end-diastolic volume, and wall motion abnormalities identify highrisk patients with previous myocardial infarction: a multiparametric http://jme.endocrinology-journals.org

DOI: 10.1530/JME-16-0128
(C) 2017 The authors Printed in Great Britain
Published by Bioscientifica Ltd 
approach for prognostic stratification. European Heart Journal $\mathbf{3 4}$ 104-111. (doi:10.1093/eurheartj/ehs037)

Dover AR, Hadoke PW, Macdonald LJ, Miller E, Newby DE \& Walker BR 2007 Intravascular glucocorticoid metabolism during inflammation and injury in mice. Endocrinology 148 166-172. (doi:10.1210/ en.2006-0996)

Edwards CR, Stewart PM, Burt D, Brett L, Mcintyre MA, Sutanto WS, De Kloet ER \& Monder C 1988 Localisation of 11 beta-hydroxysteroid dehydrogenase - tissue specific protector of the mineralocorticoid receptor. Lancet 2 986-989. (doi:10.1016/S0140-6736(88)90742-8)

Esteves CL, Kelly V, Breton A, Taylor AI, West CC, Donadeu FX, Peault B, Seckl JR \& Chapman KE 2014 Proinflammatory cytokine induction of 11beta-hydroxysteroid dehydrogenase type 1 (11betaHSD1) in human adipocytes is mediated by MEK, C/EBPbeta, and NF-kappaB/RelA. Journal of Clinical Endocrinology and Metabolism 99 E160-E168. (doi:10.1210/jc.2013-1708)

Fang YC \& Yeh CH 2015 Role of microRNAs in vascular remodeling. Current Molecular Medicine 15 684-696. (doi:10.2174/1566524015666 150921105031)

Feng X, Reini SA, Richards E, Wood CE \& Keller-Wood M 2013 Cortisol stimulates proliferation and apoptosis in the late gestation fetal heart: differential effects of mineralocorticoid and glucocorticoid receptors. American Journal of Physiology: Regulatory, Integrative and Comparative Physiology 305 R343-R350. (doi:10.1152/ajpregu.00112.2013)

Fernando MR, Giembycz MA \& Mckay DM 2015 Bidirectional crosstalk via IL-6, PGE and PGD between murine myofibroblasts and alternatively activated macrophages enhances anti-inflammatory phenotype in both cells. British Journal of Pharmacology 173 899-912. (doi:10.1111/bph.13409)

Fraccarollo D Galuppo P, Schraut S, Kneitz S, Van Rooijen N, Ertl G \& Bauersachs J 2008 Immediate mineralocorticoid receptor blockade improves myocardial infarct healing by modulation of the inflammatory response. Hypertension 51 905-914. (doi:10.1161/ HYPERTENSIONAHA.107.100941)

Fraccarollo D, Berger S, Galuppo P, Kneitz S, Hein L, Schutz G, Frantz S, Ertl G \& Bauersachs J 2011 Deletion of cardiomyocyte mineralocorticoid receptor ameliorates adverse remodeling after myocardial infarction. Circulation 123 400-408. (doi:10.1161/ CIRCULATIONAHA.110.983023)

Frangogiannis NG 2014 The inflammatory response in myocardial injury, repair, and remodelling. Nature Reviews. Cardiology 11 255-265. (doi:10.1038/nrcardio.2014.28)

Frustaci A, Letizia C, Verardo R, Grande C, Petramala L, Russo MA \& Chimenti C 2016 Cushing syndrome cardiomyopathy: clinicopathologic impact of cortisol normalization. Circulation. Cardiovascular Imaging 9 e004569. (doi:10.1161/ CIRCIMAGING.116.004569)

Funder JW 2012 Aldosterone and mineralocorticoid receptors: a personal reflection. Molecular and Cellular Endocrinology 350 146-150. (doi:10.1016/j.mce.2011.11.026)

Funder JW, Pearce PT, Smith R \& Smith AI 1988 Mineralocorticoid action: target tissue specificity is enzyme not receptor, mediated. Science 242 583-585. (doi:10.1126/science.2845584)

Furtado MB, Costa MW, Pranoto EA, Salimova E, Pinto AR, Lam NT, Park A, Snider P, Chandran A, Harvey RP, et al. 2014 Cardiogenic genes expressed in cardiac fibroblasts contribute to heart development and repair. Circulation Research 114 1422-1434. (doi:10.1161/CIRCRESAHA.114.302530)

Garcia RA, Search DJ, Lupisella JA, Ostrowski J, Guan B, Chen J, Yang WP, Truong A, He A, Zhang R, et al. 2013 11beta-hydroxysteroid dehydrogenase type 1 gene knockout attenuates atherosclerosis and in vivo foam cell formation in hyperlipidemic apoE(-)/(-) mice. PLOS ONE 8 e53192. (doi:10.1371/journal.pone.0053192)

Gomez-Sanchez EP, Romero DG, De Rodriguez AF, Warden MP, Krozowski Z \& Gomez-Sanchez CE 2008 Hexose-6-phosphate dehydrogenase and 11beta-hydroxysteroid dehydrogenase-1 tissue distribution in the rat. Endocrinology 149 525-533. (doi:10.1210/ en.2007-0328)

Gordon O, He Z, Gilon D, Gruener S, Pietranico-Cole S, Oppenheim A \& Keshet E 2014 A transgenic platform for testing drugs intended for reversal of cardiac remodeling identifies a novel 11betaHSD1 inhibitor rescuing hypertrophy independently of re-vascularization. PLOS ONE 9 e92869. (doi:10.1371/journal.pone.0092869)

Gratchev A, Kzhyshkowska J, Kannookadan S, Ochsenreiter M, Popova A, Yu X, Mamidi S, Stonehouse-Usselmann E, Muller-Molinet I, Gooi L, et al. 2008 Activation of a TGF-beta-specific multistep gene expression program in mature macrophages requires glucocorticoid-mediated surface expression of TGF-beta receptor II. Journal of Immunology 180 6553-6565. (doi:10.4049/jimmunol.180.10.6553)

Hadoke PW, Iqbal J \& Walker BR 2009 Therapeutic manipulation of glucocorticoid metabolism in cardiovascular disease. British Journal of Pharmacology 156 689-712. (doi:10.1111/j.1476-5381.2008.00047.x)

Hadoke PW, Kipari T, Seckl JR \& Chapman KE 2013 Modulation of 11beta-hydroxysteroid dehydrogenase as a strategy to reduce vascular inflammation. Current Atherosclerosis Reports 15320. (doi:10.1007/s11883-013-0320-1)

Hafezi-Moghadam A, Simoncini T, Yang Z, Limbourg FP, Plumier JC, Rebsamen MC, Hsieh CM, Chui DS, Thomas KL, Prorock AJ, et al. 2002 Acute cardiovascular protective effects of corticosteroids are mediated by non-transcriptional activation of endothelial nitric oxide synthase. Nature Medicine 8 473-479. (doi:10.1038/nm0502-473)

Hardy RS, Filer A, Cooper MS, Parsonage G, Raza K, Hardie DL, Rabbitt EH, Stewart PM, Buckley CD \& Hewison M 2006 Differential expression, function and response to inflammatory stimuli of 11beta-hydroxysteroid dehydrogenase type 1 in human fibroblasts: a mechanism for tissue-specific regulation of inflammation. Arthritis Research \& Therapy 8 R108. (doi:10.1186/ar.1993)

Harris HJ, Kotelevtsev Y, Mullins JJ, Seckl JR \& Holmes MC 2001 Intracellular regeneration of glucocorticoids by 11betahydroxysteroid dehydrogenase (11beta-HSD)-1 plays a key role in regulation of the hypothalamic-pituitary-adrenal axis: analysis of 11beta-HSD-1-deficient mice. Endocrinology 142 114-120. (doi:10.1210/endo.142.1.7887)

Hermanowski-Vosatka A, Balkovec JM, Cheng K, Chen HY, Hernandez M, Koo GC, Le Grand CB, Li Z, Metzger JM, Mundt SS, et al. 2005 11beta-HSD1 inhibition ameliorates metabolic syndrome and prevents progression of atherosclerosis in mice. Journal of Experimental Medicine 202 517-527. (doi:10.1084/jem.20050119)

Holmes MC, Kotelevtsev Y, Mullins JJ \& Seckl JR 2001 Phenotypic analysis of mice bearing targeted deletions of 11beta-hydroxysteroid dehydrogenases 1 and 2 genes. Molecular and Cellular Endocrinology 171 15-20. (doi:10.1016/S0303-7207(00)00386-5)

Horckmans M, Ring L, Duchene J, Santovito D, Schloss MJ, Drechsler M, Weber C, Soehnlein O \& Steffens S 2016 Neutrophils orchestrate post-myocardial infarction healing by polarizing macrophages towards a reparative phenotype. European Heart Journal ehw002. (doi:10.1093/eurheartj/ehw002)

Hughes KA, Webster SP \& Walker BR 2008 11-Beta-hydroxysteroid dehydrogenase type 1 (11beta-HSD1) inhibitors in type 2 diabetes mellitus and obesity. Expert Opinion on Investigational Drugs 17 481-496. (doi:10.1517/13543784.17.4.481)

Hunter RW \& Bailey MA 2015 Glucocorticoids and 11betahydroxysteroid dehydrogenases: mechanisms for hypertension. Current Opinion in Pharmacology 21 105-114. (doi:10.1016/j. coph.2015.01.005)

Iqbal J, Andrew R, Cruden NL, Kenyon CJ, Hughes KA, Newby DE, Hadoke PW \& Walker BR 2014 Displacement of cortisol from human heart by acute administration of a mineralocorticoid receptor antagonist. Journal of Clinical Endocrinology and Metabolism 99 915-922. (doi:10.1210/jc.2013-2049)

Kaur K, Hardy R, Ahasan MM, Eijken M, Van Leeuwen JP, Filer A, Thomas AM, Raza K, Buckley CD, Stewart PM, et al. 2010 Synergistic

Published by Bioscientifica Ltd. 
induction of local glucocorticoid generation by inflammatory cytokines and glucocorticoids: implications for inflammation associated bone loss. Annals of the Rheumatic Diseases 69 1185-1190. (doi:10.1136/ard.2009.107466)

Kipari T, Hadoke PW, Iqbal J, Man TY, Miller E, Coutinho AE, Zhang Z, Sullivan KM, Mitic T, Livingstone DE, et al. 2013 11betahydroxysteroid dehydrogenase type 1 deficiency in bone marrowderived cells reduces atherosclerosis. FASEB Journal 27 1519-1531. (doi:10.1096/fj.12-219105)

Klusonova P, Rehakova L, Borchert G, Vagnerova K, Neckar J, Ergang P, Miksik I, Kolar F \& Pacha J 2009 Chronic intermittent hypoxia induces 11beta-hydroxysteroid dehydrogenase in rat heart. Endocrinology 150 4270-4277. (doi:10.1210/en.2008-1493)

Kotelevtsev Y, Holmes MC, Burchell A, Houston PM, Schmoll D, Jamieson P, Best R, Brown R, Edwards CR, Seckl JR, et al. 1997 11beta-hydroxysteroid dehydrogenase type 1 knockout mice show attenuated glucocorticoid-inducible responses and resist hyperglycemia on obesity or stress. PNAS 94 14924-4929. (doi:10.1073/pnas.94.26.14924)

Kotelevtsev Y, Brown RW, Fleming S, Kenyon C, Edwards CR, Seckl JR \& Mullins JJ 1999 Hypertension in mice lacking 11beta-hydroxysteroid dehydrogenase type 2. Journal of Clinical Investigation 103 683-689. (doi:10.1172/JCI4445)

Kumari M, Shipley M, Stafford M \& Kivimaki M 2011 Association of diurnal patterns in salivary cortisol with all-cause and cardiovascular mortality: findings from the Whitehall II study. Journal of Clinical Endocrinology and Metabolism 96 1478-1485. (doi:10.1210/jc.2010-2137)

Lakshmi V \& Monder C 1988 Purification and characterization of the corticosteroid 11 beta-dehydrogenase component of the rat liver 11 beta-hydroxysteroid dehydrogenase complex. Endocrinology 123 2390-2398. (doi:10.1210/endo-123-5-2390)

Lavery GG, Walker EA, Draper N, Jeyasuria P, Marcos J, Shackleton CH, Parker KL, White PC \& Stewart PM 2006 Hexose-6-phosphate dehydrogenase knock-out mice lack 11 beta-hydroxysteroid dehydrogenase type 1-mediated glucocorticoid generation. Journal of Biological Chemistry 281 6546-6551. (doi:10.1074/jbc.M512635200)

Lefer AM 1967 Factors influencing the inotropic effect of corticosteroids. Proceedings of the Society for Experimental Biology and Medicine $\mathbf{1 2 5}$ 202-205. (doi:10.3181/00379727-125-32049)

Lefer AM 1968 Influence of corticosteroids on mechanical performance of isolated rat papillary muscles. American Journal of Physiology 214 518-524.

Libby P, Maroko PR, Bloor CM, Sobel BE \& Braunwald E 1973 Reduction of experimental myocardial infarct size by corticosteroid administration. Journal of Clinical Investigation 52 599-607. (doi:10.1172/JCI107221)

Lister K Autelitano, DJ Jenkins, A Hannan RD \& Sheppard KE 2006 Cross talk between corticosteroids and alpha-adrenergic signalling augments cardiomyocyte hypertrophy: a possible role for SGK1. Cardiovascular Research 70 555-565. (doi:10.1016/j.cardiores.2006.02.010)

McSweeney SJ 2010 11-beta hydroxysteroid dehydrogenase type 1: A new therapeutic target post-myocardial infarction? PhD thesis, The University of Edinburgh.

McSweeney SJ, Hadoke PW, Kozak AM, Small GR, Khaled H, Walker BR \& Gray GA 2010 Improved heart function follows enhanced inflammatory cell recruitment and angiogenesis in 11betaHSD1deficient mice post-MI. Cardiovascular Research 88 159-167. (doi:10.1093/cvr/cvq149)

Mihailidou AS \& Funder JW 2005 Nongenomic effects of mineralocorticoid receptor activation in the cardiovascular system. Steroids 70 347-351. (doi:10.1016/j.steroids.2005.02.004)

Mihailidou AS, Loan Le TY, Mardini M \& Funder JW 2009 Glucocorticoids activate cardiac mineralocorticoid receptors during experimental myocardial infarction. Hypertension 54 1306-1312. (doi:10.1161/HYPERTENSIONAHA.109.136242)
Mitic T, Andrew R, Walker BR \& Hadoke PW 2013a 11betaHydroxysteroid dehydrogenase type 1 contributes to the regulation of 7-oxysterol levels in the arterial wall through the inter-conversion of 7-ketocholesterol and 7beta-hydroxycholesterol. Biochimie 95 548-555. (doi:10.1016/j.biochi.2012.08.007)

Mitic T, Shave S, Semjonous N, Mcnae I, Cobice DF, Lavery GG, Webster SP, Hadoke PW, Walker BR \& Andrew R 2013b 11betaHydroxysteroid dehydrogenase type 1 contributes to the balance between 7-keto- and 7-hydroxy-oxysterols in vivo. Biochemical Pharmacology 86 146-153. (doi:10.1016/j.bcp.2013.02.002)

Morgan SA, Mccabe EL, Gathercole LL, Hassan-Smith ZK, Larner DP, Bujalska IJ, Stewart PM, Tomlinson JW \& Lavery GG 201411 betaHSD1 is the major regulator of the tissue-specific effects of circulating glucocorticoid excess. PNAS 111 E2482-E2491. (doi:10.1073/pnas.1323681111)

Newman AC, Nakatsu MN, Chou W, Gershon PD \& Hughes CC 2011 The requirement for fibroblasts in angiogenesis: fibroblast-derived matrix proteins are essential for endothelial cell lumen formation. Molecular Biology of the Cell 22 3791-3800. (doi:10.1091/mbc.E11-050393)

Oakley RH \& Cidlowski JA 2015 Glucocorticoid signaling in the heart: a cardiomyocyte perspective. Journal of Steroid Biochemistry and Molecular Biology 153 27-34. (doi:10.1016/j.jsbmb.2015.03.009)

Odermatt A \& Klusonova P 2015 11beta-hydroxysteroid dehydrogenase 1: regeneration of active glucocorticoids is only part of the story. Journal of Steroid Biochemistry and Molecular Biology 151 85-92. (doi:10.1016/j.jsbmb.2014.08.011)

Odermatt A \& Kratschmar DV 2012 Tissue-specific modulation of mineralocorticoid receptor function by 11 beta-hydroxysteroid dehydrogenases: an overview. Molecular and Cellular Endocrinology 350 168-186. (doi:10.1016/j.mce.2011.07.020)

Ouvrard-Pascaud A, Sainte-Marie Y, Benitah JP, Perrier R, Soukaseum C, Nguyen Dinh Cat A, Royer A, Le Quang K, Charpentier F, Demolombe S, et al. 2005 Conditional mineralocorticoid receptor expression in the heart leads to life-threatening arrhythmias. Circulation 111 3025-3033. (doi:10.1161/ CIRCULATIONAHA.104.503706)

Penefsky ZJ \& Kahn M 1971 Inotropic effects of dexamethasone in mammalian heart muscle. European Journal of Pharmacology $\mathbf{1 5}$ 259-266. (doi:10.1016/0014-2999(71)90091-4)

Peppa M, Ikonomidis I, Hadjidakis D, Pikounis V, Paraskevaidis I, Economopoulos T, Raptis SA \& Kremastinos DT 2009 Dilated cardiomyopathy as the predominant feature of Cushing's syndrome. American Journal of the Medical Sciences 338 252-253. (doi:10.1097/ MAJ.0b013e3181a927e0)

Pitt B, Zannad F, Remme WJ, Cody R, Castaigne A, Perez A, Palensky J \& Wittes J 1999 The effect of spironolactone on morbidity and mortality in patients with severe heart failure. Randomized Aldactone Evaluation Study Investigators. New England Journal of Medicine 341 709-717. (doi:10.1056/NEJM199909023411001)

Pitt B, Remme W, Zannad F, Neaton J, Martinez F, Roniker B, Bittman R, Hurley S, Kleiman J \& Gatlin M 2003 Eplerenone, a selective aldosterone blocker, in patients with left ventricular dysfunction after myocardial infarction. New England Journal of Medicine 348 1309-1321. (doi:10.1056/NEJMoa030207)

Pitt B, Bakris G, Ruilope LM, Dicarlo L \& Mukherjee R 2008 Serum potassium and clinical outcomes in the Eplerenone Post-Acute Myocardial Infarction Heart Failure Efficacy and Survival Study (EPHESUS). Circulation 118 1643-1650. (doi:10.1161/ CIRCULATIONAHA.108.778811)

Porter KE \& Turner NA 2009 Cardiac fibroblasts: at the heart of myocardial remodeling. Pharmacology \& Therapeutics 123 255-278. (doi:10.1016/j.pharmthera.2009.05.002)

Qin W, Rudolph AE, Bond BR, Rocha R, Blomme EA, Goellner JJ, Funder JW \& Mcmahon EG 2003 Transgenic model of aldosterone- http://jme.endocrinology-journals.org

DOI: $10.1530 / \mathrm{JME}-16-0128$
() 2017 The authors Printed in Great Britain
Published by Bioscientifica Ltd 
driven cardiac hypertrophy and heart failure. Circulation Research 93 69-76. (doi:10.1161/01.RES.0000080521.15238.E5)

Rahman TJ, Mayosi BM, Hall D, Avery PJ, Stewart PM, Connell JM, Watkins H \& Keavney B 2011 Common variation at the 11-beta hydroxysteroid dehydrogenase type 1 gene is associated with left ventricular mass. Circulation: Cardiovascular Genetics 4 156-162. (doi:10.1161/circgenetics.110.958496)

Richardson RV, Batchen EJ, Denvir MA, Gray GA \& Chapman KE 2016 Cardiac GR and MR: from development to pathology. Trends in Endocrinology and Metabolism 27 35-43. (doi:10.1016/j. tem.2015.10.001)

Rog-Zielinska EA, Thomson A, Kenyon CJ, Brownstein DG, Moran CM, Szumska D, Michailidou Z, Richardson J, Owen E, Watt A, et al. 2013 Glucocorticoid receptor is required for foetal heart maturation. Human Molecular Genetics 22 3269-3282. (doi:10.1093/hmg/ddt182)

Rog-Zielinska EA, Richardson RV, Denvir MA \& Chapman KE 2014 Glucocorticoids and foetal heart maturation; implications for prematurity and foetal programming. Journal of Molecular Endocrinology 52 R125-R135. (doi:10.1530/JME-13-0204)

Rog-Zielinska EA, Craig MA, Manning JR, Richardson RV, Gowans GJ, Dunbar DR, Gharbi K, Kenyon CJ, Holmes MC, Hardie DG, et al. 2015 Glucocorticoids promote structural and functional maturation of foetal cardiomyocytes: a role for PGC-1alpha. Cell Death \& Differentiation 22 1106-1116. (doi:10.1038/cdd.2014.181)

Sai S, Esteves CL, Kelly V, Michailidou Z, Anderson K, Coll AP, Nakagawa Y, Ohzeki T, Seckl JR \& Chapman KE 2008 Glucocorticoid regulation of the promoter of 11beta-hydroxysteroid dehydrogenase type 1 is indirect and requires CCAAT/enhancer-binding proteinbeta. Molecular Endocrinology 22 2049-2060. (doi:10.1210/me.20070489)

Samarasinghe RA, Witchell SF \& Defranco DB 2012 Cooperativity and complementarity: synergies in non-classical and classical glucocorticoid signaling. Cell Cycle 11 2819-2827. (doi:10.4161/ cc.21018)

Schafer HH, Dieterle T, Trachsler A, Gencay M \& Kaiser EA 2015 Bridging the gap: the potential role of corticosteroid binding globulin in cardiac steroid facilitation. Current Drug Targets $\mathbf{1 6}$ 1254-1269. (doi:10.2174/1389450116666150408103806)

Sheppard KE \& Autelitano DJ 2002 11Beta-hydroxysteroid dehydrogenase 1 transforms 11-dehydrocorticosterone into transcriptionally active glucocorticoid in neonatal rat heart. Endocrinology 143 198-204. (doi:10.1210/en.143.1.198)

Shibusawa N, Yamada M, Hashida T, Hashimoto K, Satoh T, Horiguchi J, Oyama T, Takeyoshi I \& Mori M 2015 Dilated cardiomyopathy as a presenting feature of Cushing's syndrome. Internal Medicine $\mathbf{5 2}$ 1067-1071. (doi:10.2169/internalmedicine.52.9051)

Shinde AV \& Frangogiannis NG 2014 Fibroblasts in myocardial infarction: a role in inflammation and repair. Journal of Molecular and Cellular Cardiology 70 74-82. (doi:10.1016/j.yjmcc.2013.11.015)

Shiraishi M, Shintani Y, Shintani Y, Ishida H, Saba R, Yamaguchi A, Adachi H, Yashiro K \& Suzuki K 2016 Alternatively activated macrophages determine repair of the infarcted adult murine heart. Journal of Clinical Investigation 126 2151-2166. (doi:10.1172/ JCI85782)

Skyschally A, Haude M, Dorge H, Thielmann M, Duschin A, Van De Sand A, Konietzka I, Buchert A, Aker S, Massoudy P, et al. 2004 Glucocorticoid treatment prevents progressive myocardial dysfunction resulting from experimental coronary microembolization. Circulation 109 2337-2342. (doi:10.1161/01. CIR.0000127961.66744.F4)

Small GR, Hadoke PW, Sharif I, Dover AR, Armour D, Kenyon CJ, Gray GA \& Walker BR 2005 Preventing local regeneration of glucocorticoids by 11beta-hydroxysteroid dehydrogenase type 1 enhances angiogenesis. PNAS 102 12165-12170. (doi:10.1073/ pnas.0500641102)
Smith JB \& Herschman HR 1995 Glucocorticoid-attenuated response genes encode intercellular mediators, including a new C-X-C chemokine. Journal of Biological Chemistry 270 16756-16765. (doi:10.1074/jbc.270.28.16756)

Smith RE, Little PJ, Maguire JA, Stein-Oakley AN \& Krozowski ZS 1996 Vascular localization of the 11 beta-hydroxysteroid dehydrogenase type II enzyme. Clinical and Experimental Pharmacology \& Physiology 23 549-551.

Sooy K, Noble J, Mcbride A, Binnie M, Yau JL, Seckl JR, Walker BR \& Webster SP 2015 Cognitive and disease-modifying effects of 11 betahydroxysteroid dehydrogenase type 1 inhibition in male Tg2576 mice, a model of Alzheimer's disease. Endocrinology 156 4592-4603. (doi:10.1210/en.2015-1395)

Souverein PC, Berard A, Van Staa TP, Cooper C, Egberts AC, Leufkens HG \& Walker BR 2004 Use of oral glucocorticoids and risk of cardiovascular and cerebrovascular disease in a population based case-control study. Heart 90 859-865. (doi:10.1136/hrt.2003.020180)

Speirs HJ, Seckl JR \& Brown RW 2004 Ontogeny of glucocorticoid receptor and 11beta-hydroxysteroid dehydrogenase type-1 gene expression identifies potential critical periods of glucocorticoid susceptibility during development. Journal of Endocrinology $\mathbf{1 8 1}$ 105-116. (doi:10.1677/joe.0.1810105)

Stegk JP, Ebert B, Martin HJ \& Maser E 2009 Expression profiles of human 11beta-hydroxysteroid dehydrogenases type 1 and type 2 in inflammatory bowel diseases. Molecular and Cellular Endocrinology 301 104-108. (doi:10.1016/j.mce.2008.10.030)

Suresh R, Li X, Chiriac A, Goel K, Terzic A, Perez-Terzic C \& Nelson TJ 2014 Transcriptome from circulating cells suggests dysregulated pathways associated with long-term recurrent events following firsttime myocardial infarction. Journal of Molecular and Cellular Cardiology 74 13-21. (doi:10.1016/j.yjmcc.2014.04.017)

Tiganescu A, Walker EA, Hardy RS, Mayes AE \& Stewart PM 2011 Localization, age- and site-dependent expression, and regulation of 11beta-hydroxysteroid dehydrogenase type 1 in skin. Journal of Investigative Dermatology 131 30-36. (doi:10.1038/jid.2010.257)

Tiganescu A, Tahrani AA, Morgan SA, Otranto M, Desmouliere A, Abrahams L, Hassan-Smith Z, Walker EA, Rabbitt EH, Cooper MS, et al. 2013 11beta-Hydroxysteroid dehydrogenase blockade prevents age-induced skin structure and function defects. Journal of Clinical Investigation 123 3051-3060. (doi:10.1172/JCI64162)

Turner NA 2016 Inflammatory and fibrotic responses of cardiac fibroblasts to myocardial damage associated molecular patterns (DAMPs). Journal of Molecular and Cellular Cardiology 94 189-200. (doi:10.1016/j.yjmcc.2015.11.002)

Uhlenhaut NH, Barish GD, Yu RT, Downes M, Karunasiri M, Liddle C, Schwalie P, Hubner N \& Evans RM 2013 Insights into negative regulation by the glucocorticoid receptor from genome-wide profiling of inflammatory cistromes. Molecular Cell 49 158-171. (doi:10.1016/j.molcel.2012.10.013)

Ullian ME 1999 The role of corticosteriods in the regulation of vascular tone. Cardiovascular Research 41 55-64. (doi:10.1016/S00086363(98)00230-2)

Usher MG, Duan SZ, Ivaschenko CY, Frieler RA, Berger S, Schutz G, Lumeng CN \& Mortensen RM 2010 Myeloid mineralocorticoid receptor controls macrophage polarization and cardiovascular hypertrophy and remodeling in mice. Journal of Clinical Investigation 120 3350-3364. (doi:10.1172/JCI41080)

Van Nieuwenhoven FA \& Turner NA 2013 The role of cardiac fibroblasts in the transition from inflammation to fibrosis following myocardial infarction. Vascular Pharmacology 58 182-188. (doi:10.1016/j. vph.2012.07.003)

Velagaleti RS, Pencina MJ, Murabito JM, Wang TJ, Parikh NI, D'agostino RB, Levy D, Kannel WB \& Vasan RS 2008 Long-term trends in the incidence of heart failure after myocardial infarction. Circulation 118 2057-2062. (doi:10.1161/CIRCULATIONAHA.108.784215) http://jme.endocrinology-journals.org

DOI: 10.1530/JME-16-0128
(C) 2017 The authors Printed in Great Britain
Published by Bioscientifica Ltd 
Walker BR, Yau JL, Brett LP, Seckl JR, Monder C, Williams BC \& Edwards CR 199111 beta-hydroxysteroid dehydrogenase in vascular smooth muscle and heart: implications for cardiovascular responses to glucocorticoids. Endocrinology 129 3305-3312. (doi:10.1210/endo129-6-3305)

Wan E, Yeap XY, Dehn S, Terry R, Novak M, Zhang S, Iwata S, Han X, Homma S, Drosatos K, et al. 2013 Enhanced efferocytosis of apoptotic cardiomyocytes through myeloid-epithelial-reproductive tyrosine kinase links acute inflammation resolution to cardiac repair after infarction. Circulation Research 113 1004-1012. (doi:10.1161/ CIRCRESAHA.113.301198)

Wei L, Macdonald TM \& Walker BR 2004 Taking glucocorticoids by prescription is associated with subsequent cardiovascular disease. Annals of Internal Medicine 141 764-770. (doi:10.7326/0003-4819141-10-200411160-00007)

Wheelan N, Webster SP, Kenyon CJ, Caughey S, Walker BR, Holmes MC, Seckl JR \& Yau JL 2014 Short-term inhibition of 11betahydroxysteroid dehydrogenase type 1 reversibly improves spatial memory but persistently impairs contextual fear memory in aged mice. Neuropharmacology 91 71-76. (doi:10.1016/j. neuropharm.2014.12.005)

White CI 2016 Cardiovascular 11 $\beta$-HSD1: its role in myocardial physiology and pathophysiology. PhD thesis, The University of Edinburgh.

White CI, Jansen MA, Mcgregor K, Mylonas KJ, Richardson RV, Thomson A, Moran CM, Seckl JR, Walker BR, Chapman KE, et al. 2016 Cardiomyocyte and vascular smooth muscle-independent 11beta-hydroxysteroid dehydrogenase 1 amplifies infarct expansion, hypertrophy, and the development of heart failure after myocardial infarction in male mice. Endocrinology 157 346-357. (doi:10.1210/ en.2015-1630)
Whorwood CB, Franklyn JA, Sheppard MC \& Stewart PM 1992 Tissue localization of 11 beta-hydroxysteroid dehydrogenase and its relationship to the glucocorticoid receptor. Journal of Steroid Biochemistry and Molecular Biology 41 21-28. (doi:10.1016/09600760(92)90220-D)

Zannad F, Mcmurray JJ, Krum H, Van Veldhuisen DJ, Swedberg K, Shi H, Vincent J, Pocock SJ \& Pitt B 2011 Eplerenone in patients with systolic heart failure and mild symptoms. New England Journal of Medicine 364 11-21. (doi:10.1056/NEJMoa1009492)

Zannad F, Gattis Stough W, Rossignol P, Bauersachs J, Mcmurray JJ, Swedberg K, Struthers AD, Voors AA, Ruilope LM, Bakris GL, et al. 2012 Mineralocorticoid receptor antagonists for heart failure with reduced ejection fraction: integrating evidence into clinical practice. European Heart Journal 33 2782-2795. (doi:10.1093/eurheartj/ ehs257)

Zhang TY \& Daynes RA 2007 Macrophages from 11beta-hydroxysteroid dehydrogenase type 1-deficient mice exhibit an increased sensitivity to lipopolysaccharide stimulation due to TGF-beta-mediated up-regulation of SHIP1 expression. Journal of Immunology 179 6325-6335. (doi:10.4049/jimmunol.179.9.6325)

Zhang TY, Ding X \& Daynes RA 2005 The expression of 11 betahydroxysteroid dehydrogenase type I by lymphocytes provides a novel means for intracrine regulation of glucocorticoid activities. Journal of Immunology 174 879-889. (doi:10.4049/ jimmunol.174.2.879)

Zhao X, Wu J, Gray CD, Mcgregor K, Rossi AG, Morrison H, Jansen MA \& Gray GA 2015 Optical projection tomography permits efficient assessment of infarct volume in the murine heart postmyocardial infarction. American Journal of Physiology: Heart and Circulatory Physiology 309 H702-H710. (doi:10.1152/ajpheart.00233.2015)

Received in final form 17 August 2016

Accepted 19 August 2016

Accepted Preprint published online 23 August 2016 http://jme.endocrinology-journals.org

DOI: 10.1530/JME-16-0128
() 2017 The authors Printed in Great Britain
Published by Bioscientifica Ltd 